\title{
PENGARUH SENAM DAN AEROBIK TERHADAP RESIKO JATUH PADA LANSIA DI DESA SOBOKERTO KECAMATAN NGEMPLAK BOYOLALI JAWA TENGAH
}

\author{
Ninik Nurhidayah \\ Kementerian Kesehatan Politeknik Kesehatan Surakarta Jurusan Okupasi Terapi
}

\begin{abstract}
Elders, Aerobic. Decreased physical function of the elderly causes the risk of falling. Falling in the elderly can lead to injury. Injuries that occur can lead to serious disability in the elderly. This study aims to determine to determine the effect of gymnastics and aerobics against the risk of falling in the elderly in the Village Sobokerto Ngemplak Boyolali District. The study was conducted with quasi experimental design. The sampling technique with random sampling. Total sample of 30 elderly consisting of 15 persons and 15 persons group gymnastics aerobics group. The research instrument used Tinetti test. The pre-test was conducted to determine the risk of falls of elderly before gymnastics and aerobics. Post-test performed after gymnastics and aerobics. Gymnastics and aerobics done 3 times/week for about 4 weeks with a duration of 20-30 minutes. Analysis of the data with the t-test. The significance level $(\alpha=0.05)$ and local criticism $(d k)$ with $d k=N-1$. The value of $t$ count on gymnastics group is-1853, with a significance value (probability) 0.084. Therefore we can conclude there is no influence of exercise on the risk of falls in the elderly village Ngemplak Sobokerto District of Boyolali. T-count the aerobic group is -3290, with a significance value (probability) of 0.005. This means that the aerobic effect in reducing the risk of falls in the elderly Sobokerto Village District of Ngemplak Boyolali Central of Java. There is an aerobic effect on the risk of falls in the elderly village Ngemplak Sobokerto District of Boyolali.
\end{abstract}

Keywords: Elders, Aerobic

Abstrak : Lansia, Aerobik. Penurunan fungsi fisik lansia menyebabkan resiko jatuh. Jatuh pada lansia dapat mengakibatkan injuri. Injuri yang terjadi dapat mengakibatkan disabilitas yang serius pada lansia. Penelitian ini bertujuan untuk mengetahui untuk mengetahui pengaruh senam dan aerobik terhadap resiko jatuh pada lansia di Desa Sobokerto Kecamatan Ngemplak Boyolali. Penelitian dilakukan dengan desain quasi eksperimental. Teknik pengambilan sampel dengan random sampling. Jumlah sampel sebanyak 30 orang lansia terdiri dari 15 orang kelompok senam dan 15 orang kelompok aerobik. Instrumen menggunakan tes Tinetti. Senam dan aerobik dilakukan sebanyak 3 kali/minggu selama kurang lebih 4 minggu dengan durasi 20-30 menit. Tehnik analisis data dengan t-test. Tingkat signifikansi $(\alpha=0,05)$ dan daerah kritik $(\mathrm{dk})$ dengan $\mathrm{dk}=\mathrm{N}$ - 1. Nilai thitung pada kelompok senam adalah -1.853, dengan nilai signifikansi (probabilitas) 0,084. Nilai thitung pada kelompok aerobik adalah -3.290, dengan nilai signifikansi (probabilitas) 0,005. Penelitian menunjukkan terdapat perbedaan yang signifikan pada resiko jatuh lansia sebelum dan sesudah aerobik di Desa Sobokerto Kecamatan Ngemplak Boyolali. Penelitian ini menunjukkan bahwa aerobik 
berpengaruh dalam menurunkan resiko jatuh lansia di Desa Sobokerto Kecamatan Ngemplak

Kata Kunci: Lansia, Aerobik

\section{PENDAHULUAN}

Usia atau angka harapan hidup penduduk Indonesia telah meningkat secara bermakna pada beberapa dekade terakhir ini. Disamping peningkatan harapan hidup, jumlah dan proporsi kelompok lanjut usia (lansia) di negara kita pun menunjukkan kecenderungan yang meningkat, yaitu 5,3 juta jiwa atau $4,48 \%$ pada tahun 1971, 12,7 juta jiwa atau $6,56 \%$ pada tahun 1990 dan akan meningkat tajam menjadi 28,8 juta jiwa atau $11,34 \%$ pada tahun 2010 (Kuntjoro, 2002).

Lansia mengalami penurunan fungsi kognitif dapat menyebabkan demensia dan delirium, dimana keadaan ini dapat membahayakan lansia dalam menjalani aktivitas sehari-hari. Kecelakaan-kecelakaan kecil dapat terjadi akibat penurunan kewaspadaan, rasa cemas dan ketakutan dapat meningkat akibat gangguan orientasi, dan bertambah buruknya dampak psikososial diakibatkan karena fungsi berbahasa yang menurun. Ditambah fungsi daya ingat (memori) yang menurun menyebabkan bertambahnya masalah pada lansia (Nyimas, 2010).

Hasil penelitian menunjukkan bahwa terjadi penurunan fungsi tubuh pada lansia, antara lain : penglihatan $(76,24 \%)$, daya ingat $(69,39 \%)$, seksual $(58,04 \%)$, kelenturan $(53,23 \%)$, gigi dan mulut $(51,12 \%)$ (Forum Masyarakat Sehat dan Sejahtera,2009). Keadaan ini cenderung berpotensi menimbulkan masalah kesehatan secara umum maupun kesehatan jiwa secara khusus pada lansia (Kuntjoro, 2002).

Jatuh dapat terjadi pada siapa saja. Namun resiko jatuh menjadi lebih besar dapat terjadi pada lansia. Penurunan fungsi fisik lansia menyebabkan resiko jatuh. Jatuh pada lansia dapat mengakibatkan injuri. Injuri yang terjadi dapat mengakibatkan disabilitas yang serius pada lansia (Darmojo \& Martono, 2000)

Physical activity secara teratur sangat penting untuk mempertahankan kondisi fisik lansia, menurunkan resiko jatuh dan menjadi jalan untuk dapat hidup mandiri. Banyak manfaat yang diperoleh dengan melakukan physical activity. Manfaat melakukan physical activity yang teratur antara lain dapat meningkatkan massa otot, menurunkan resiko osteoporosis, menjadikan tulang menjadi kuat, mempertahankan fungsi fisik dan kemandirian dalam kehidupan sehari-hari.

Desa Sobokerto Kecamatan Ngemplak Boyolali sudah terdapat posyandu lansia, namun belum pernah dilakukan penelitian tentang pengaruh aerobik pada lansia. Kegiatan yang dilakukan adalah penyuluhan, terapi aktivitas, terapi kelompok, terapi kognitif, senam lansia dan lain-lain. Mengingat besarnya manfaat aktivitas fisik pada lansia untuk kondisi fisiknya, maka peneliti ingin mengetahui apakah ada pengaruh aerobik terhadap resiko jatuh pada lansia didesa Sobokerto Kecamatan Ngemplak Boyolali. 


\section{METODE PENELITIAN}

Jenis penelitian ini adalah Penelitian ini merupakan penelitian quasi eksperimental. Tempat pelaksanaannya di Desa Sobokerto Kecamatan Ngemplak Boyolali. Tehnik pengambilan sampel dengan random sampling. Kriteria inklusinya: lansia berusia lebih dari 60 tahun, tingkat kesadaran cukup baik (tempat, waktu, orang), dan mampu berjalan secara mandiri atau dengan bantuan (tongkat). Kriteria eksklusi: lansia dengan infeksi akut, terminal disease, patah tulang akut, severe circulatatory disease, lansia pada long term care maupun lansia yang hanya beraktivitas di bed

\section{HASIL PENELITIAN}

Jumlah total populasi dalam penelitian ini sebanyak 57 lansia. Jumlah sampel yang didapat dalam penelitian adalah 30 sampel. Adapun keseluruhan sampel adalah perempuan. Sampel terbagi menjadi dua kelompok yaitu 15 orang lansia kelompok senam dan 15 orang lansia kelompok aerobik.

\section{Tabel 1}

\begin{tabular}{lcc}
\multicolumn{3}{c}{ Distribusi Usia Sampel Penelitian } \\
\hline \multicolumn{1}{c}{ Usia } & $\begin{array}{c}\text { Frekuensi } \\
\text { senam (\%) }\end{array}$ & $\begin{array}{c}\text { Frekuensi } \\
\text { aerobik (\%) }\end{array}$ \\
\hline $\begin{array}{l}60-74 \text { tahun } \\
\text { (elderly) }\end{array}$ & $8(53.3)$ & $12(80)$ \\
$\begin{array}{l}75-90 \text { tahun } \\
\text { (old) }\end{array}$ & $4(26.7)$ & $2(13.3)$ \\
$\begin{array}{l}>90 \text { tahun } \\
\text { (very old) }\end{array}$ & $3(20)$ & $1(6.7)$ \\
$\quad$ Total & $\mathbf{1 5}$ & $\mathbf{1 5}$ \\
\hline
\end{tabular}

Alat analisis yang digunakan adalah t-test dengan bantuan program SPSS 17.0 for Windows. Suatu uji dianggap terdapat perbedaan yang signifikan jika nilai $p$-value (signifikansi hitung) lebih kecil dari nilai signifikansi yang ditetapkan yaitu 0,05 . Pengujian $t$ test ini menggunakan total score tonetti's tes sebelum dan sesudah dilakukan senam dan aerobik.

Sebelum dilakukan uji t-test perlu dilakukan uji homogenitas dan normalitas data terlebih dahulu. Uji homogenitas data diperoleh signifikansi 0.802. Nilai signifikansi tersebut menunjukkan nilai yang lebih tinggi dari 0.05. Dengan demikian dapat disimpulkan bahwa data pre dan pos test bersifat homogen.

Hasil uji normalitas data didapat nilai 1.420 dengan taraf signifikansi 0,035 pada pre-tes senam dan 1.448 dengan taraf signifikansi 0.030 pada post-test senam. Sedangkan pada pretes aerobik didapatkan hasil 1.427 dengan taraf signifikansi 0.034 dan 1.143 dengan taraf signifikansi 0.031 pada post-test aerobik. Hasil tersebut menunjukkan bahwa data berdistribusi normal.

Berdasarkan hasil analisis t-test maka diinterpretasikan sebagai berikut: Tingkat signifikansi $(\alpha=0,05)$ dan daerah kritik (dk) dengan $\mathrm{dk}=\mathrm{N}-1$. Nilai $\mathrm{t}_{\text {hitung }}$ pada kelompok senam dengan menggunakan bantuan program SPSS 17.0 for Windows adalah -1.853, dengan nilai signifikansi (probabilitas) 0,084. Keputusan $\mathrm{H}_{0}$ diterima jika $\mathrm{t}_{\text {hitung }}<\mathrm{t}_{\text {tabel }}$ atau $t_{\text {hitung }}>-t_{\text {tabel }}$; atau probabilitas $>0,05$ dan $\mathrm{H}_{0}$ ditolak jika $t_{\text {hitung }}>t_{\text {tabel }}$ dan $t_{\text {hitung }}<-$ $\mathrm{t}_{\text {tabel }}$; atau probabilitas $<0,05$, karena nilai t hitung $(-1.853)<\mathrm{t}$ tabel $(2,14)$, maka $\mathrm{H}_{\mathrm{a}}$ ditolak. Sehingga dapat disimpulkan tidak ada pengaruh senam terhadap resiko jatuh lansia di Desa Sobokerto Kecamatan Ngemplak Boyolali.

Tingkat signifikansi $(\alpha=0,05)$ dan daerah kritik (dk) dengan $\mathrm{dk}=\mathrm{N}-1$. Nilai $t_{\text {hitung }}$ pada kelompok aerobik dengan menggunakan bantuan program SPSS 17.0 for Windows adalah -3.290, dengan nilai 
signifikansi (probabilitas) 0,005 . Keputusan $\mathrm{H}_{0}$ diterima jika $\mathrm{t}_{\text {hitung }}<\mathrm{t}_{\text {tabel }}$ atau $t_{\text {hitung }}>-t_{\text {tabel }}$; atau probabilitas $>0,05$ dan $\mathrm{H}_{0}$ ditolak jika $t_{\text {hitung }}>\mathrm{t}_{\text {tabel }}$ dan $\mathrm{t}_{\text {hitung }}<-$ $\mathrm{t}_{\text {tabel }}$; atau probabilitas $<0,05$, karena nilai $\mathrm{t}$ hitung $(-3,290)>\mathrm{t}$ tabel $(2,14)$, maka $\mathrm{H}_{0}$ ditolak. Sehingga dapat disimpulkan ada pengaruh aerobik terhadap resiko jatuh lansia di Desa Sobokerto.

Hasil ini menunjukkan bahwa terdapat perbedaan yang signifikan terhadap resiko jatuh lansia di Desa Sobokerto Kecamatan Ngemplak Boyolali sebelum dan sesudah aerobik. Sedangkan pada senam tidak menunjukkan perbedaan yang signifikan terhadap resiko jatuh lansia di Desa Sobokerto Kecamatan Ngemplak Boyolali.

\section{PEMBAHASAN}

Perbedaan tingkat resiko jatuh pada aktivitas senam dan aerobik di Desa Sobokerto Kecamatan Ngemplak Boyolali diantaranya dipengaruhi oleh faktor: usia, kondisi kesehatan dan frekuensi mengikuti aktivitas.

Usia sangat berpengaruh terhadap resiko jatuh. Dalam penelitian ini terbukti bahwa terdapat perbedaan yang signifikan pada kelompok lansia yang melakukan aerobik dibandingkan dengan kelompok lansia yang melakukan senam. Hal ini dapat dilihat pada perbedaan secara deskriptif, rentang usia pada kedua kelompok penelitian. Pada kelompok senam memiliki rentang usia yang lebih banyak dibandingkan kelompok aerobik. Rentang usia pada kelompok senam berkisar antara 46 sampai 102 tahun, sedangkan pada kelompok aerobik berkisar 46 sampai 92 tahun. Sebagaimana diketahui bahwa lansia mengalami berbagai kemunduran seiring dengan bertambahnya usia.
Dalam American College of Sports Medicine (2009) disebutkan hampir separuh penurunan kapasitas fisik berkaitan dengan proses penuaan yang mungkin terjadi karena kurangnya aktivitas fisik. Tanpa latihan rutin, individu yang telah berusia di atas 50 tahun dapat beresiko mengalami masalah kesehatan yang berupa: menurunnya masa, dan kekuatan otot serta menurunnya daya tahan fisik; menurunnya kemampuan koordinasi dan keseimbangan; berkurangnya fleksibilitas sendi dan mobilitas; menurunnya fungsi kardiovaskular dan respirasi; berkurangnya kekuatan tulang, meningkat jumlah lemak dan tekanan darah serta gangguan mood, seperti kecemasan dan depresi; meningkat resiko berbagai penyakit termasuk penyakit kardiovaskular dan stroke.

Burbank et al. (2002); Dayhoff \& Moore (1998) menjelaskan bahwa pada rentang umur lebih 60 tahun wanita menghadapi beberapa masalah kesehatan. Salah satu masalah adalah kelenturan badan. Penurunan kelenturan badan pada lansia dapat menurunkan tingkat kebugaran fisik, aktivitas fisik, dan sebagai faktor resiko yang dapat berakibat patah tulang dan kecacatan.

Beberapa ahli, yaitu Burbank et al. (2002), Butler et al. (1998), Evans (2002), Nied \& Franklin (2002), McArdle et al. (2001), meresepkan olahraga bagi lansia adalah olahraga yang berunsur gerak memadukan gerak untuk melatih keseimbangan, dengan pembebanan yang memacu kekuatan otot, peregangan untuk meningkatkan kelenturan badan dan kontraksi otot-otot badan hingga dapat memacu kerja jantung dan paru-paru.

McArdle (2001); Giam \& The (1993) juga menyebutkan bahwa salah 
satu jenis olahraga yang direkomendasikan untuk lansia adalah senam aerobic low impact dengan intensitas ringan-sedang, durasi 20-50 menit, frekuensi tiga kali perminggu.

Kondisi kesehatan yang di alami oleh lansia berpengaruh terhadap resiko jatuh. Hal-hal yang berkaitan dengan faktor resiko jatuh adalah sistem sensorik, sistem saraf pusat, kognitif, dan muskuloskeletal. Sistem sensorik yang berperan dalam faktor resiko jatuh adalah visus (penglihatan), pendengaran, fungsi vestibuler, dan proprioceptif.

Muskuloskeletal merupakan faktor utama yang menyebabkan lansia jatuh (Reuben, Tinetti, Kane, Campbell, Brocklehurst seperti ditulis kembali oleh Darmojo \& Martono, 2000). Gangguan muskuloskeletal menyebabkan gangguan gaya berjalan dan berhubungan dengan proses menua yang fisiologis. Gangguan gaya berjalan yang terjadi akibat proses menua tersebut disebabkan oleh kekakuan jaringan penghubung, berkurangnya masa otot, perlambatan konduksi saraf, penurunan visus, kerusakan proprioceptif.

Kondisi tersebut akan menyebabkan penurunan lingkup gerak sendi, penurunan kekuatan otot yang berakibat melemahnya ekstremitas bawah, perpanjangan waktu reaksi, kerusakan persepsi dalam dan peningkatan postural sway .

Semua perubahan tersebut mengakibatkan kelambanan gerak, langkah yang pendek, penurunan irama berjalan. Kaki tidak dapat menapak dengan kuat dan lebih cenderung mudah goyah. Perlambatan reaksi mengakibatkan seorang lansia susah/ terlambat mengantisipasi bila terjadi gangguan seperti terpeleset, tersandung, kejadian tiba-tiba, sehingga memudahkan jatuh.
Pada umumnya penyebab lansia jatuh adalah gabungan dari beberapa faktor antara lain: 1) kecelakaan yang merupakan penyebab jatuh yang utama sekitar 30-50 \% kasus, 2) nyeri kepala dan atau vertigo, 3) hipotensi orthostatic, 4) obat-obatan seperti diuretik/antihipertensi, antidepresan, sedativa, antipsikotik, obatobat hipoglikemik, 5) proses penyakit yang spesifik seperti penyakit kardiovaskuler, neurologi, 6) sinkope (kehilangan kesadaran secara tiba-tiba (Darmojo \& Martono, 2000).

\section{KESIMPULAN DAN SARAN}

Frekuensi lansia dalam mengikuti aktivitas senam dan aerobik mempengaruhi resiko jatuh. Melakukan aktivitas fisik secara regular akan berdampak positif pada kesehatan lansia. Latihan fisik yang dilakukan secara rutin oleh lansia memberikan manfaat pada berbagai hal seperti : 1) Otot: meningkatkan masa otot dalam jangka waktu pendek, 2) tulang: mengurangi resiko hilangnya tulang dan osteoporosis dan latihan dengan fokus pada keseimbangan distribusi beban tubuh dapat membantu tulang menjadi lebih kuat dan sehat, 3) Jantung dan paru: latihan dengan intensitas sedang lebih diutamakan, 4) Persendian: semua persendian dalam tubuh perlu digerakkan untuk mempertahankan kesehatan, 5) Jumlah lemak tubuh: latihan fisik secara rutin dapat membakar lemak, meningkatkan masa otot dan kecepatan metabolisme tubuh, sehingga seiring perubahan fisiologis lansia dapat mempertahankan berat badan yang sesuai, 6) mempertahankan fungsi fisik dan kemandirian hidup, 7) Memperbaiki interaksi sosial, kualitas hidup dan mengurangi depresi, 8) Mengurangi resiko 
injuri karena jatuh, 9) Mengurangi resiko penyakit jantung,stroke,tekanan darah tinggi, diabetes tipe II dan kanker, 10) Stimulasi multimodal, 11) Memperbaiki reaksi dan perencanaan gerakan (American Journal of Prevention Medicine, 2010). Disebutkan pula bahwa aktivitas fisik yang teratur meningkatkan harapan hidup rata-rata dan berhubungan dengan kesehatan secara umum, kesejahteraan dan kapasitas fungsionalnya.

Meskipun hasil penelitian senam terhadap resiko jatuh pada lansia di Desa Sobokerto Kecamatan Ngemplak Boyolali secara statistik tidak signifikan namun perlu dipahami bahwa hasil secara deskriptif tidak menunjukkan peningkatan resiko jatuh pada sampel penelitian. Sehingga sejalan dengan proses menua yang dialaminya senam dapat mempertahankan kondisi fisik agar tetap bugar dan sehat. Sampel juga merasa senang dan bersemangat untuk mengikuti program latihan yang diberikan. Mayoritas lansia menyatakan bahwa tubuhnya merasa lebih bugar, lebih sehat dan enak.

\section{DAFTAR RUJUKAN}

American Journal of Prevention Medicine (2010). Cost effectiveness of community-based physical activity interventions. volume 35 ,issue 6 , pages 578-588, December 2008. Available: http://www.ajpmonline.net/article/S07493797(08)00770-8/abstract

Burbank PM. ReibeD. PadulaCA.\& Nigg C. (2002). Exercise and older adults: changing behavior with the transtheoretical model. Orthopaedic Nursing; 21(4):51-63
Butler RN. Davis R. Lewis CB. Nelson ME. \& Strauss E.(1998). Exercise prescription for older adults. Geriatrics:53(11):45-56

Chodzko-Zajko WJ. Proctor DN. Maria. Fiatarone MA. Minson CT. Nigg CR. Salem GJ. Skinner JS. (2009). Exercice and physical activity for older adults. American College for Sports Medicine.

Darmojo, R. B. \& Martono, H. H. (2000). Buku ajar geriatri. Jakarta: Balai Penerbit FKUI

Dayhoff NE. Suhrheinrich J. Wigglesworth J. Opp R. and Moore S. (1998). Balance and muscle strength aspredictors of neuromuscular performance, functional status and falls between Japanese and white women. Journal Gerontol: 54A(6): M288M292

Giam CK and The KC.(1993).Ilmu kedokteran olahraga. Jakarta: Binarupa Aksara

Kuntjoro, Z.S. (2002). Masalah kesehatan jiwa lansia. Retrived Desember 4 2010 from: http://www.epsikologi.com/epsi/la njutuisa_detail.asp?id=182-17k- .

McArdle WD. Katch FI \& Katch FL. (2001). ExercisePhysiology. $5^{\text {th }}$ ed. Tokyo: Lippincot Williams \& Wilkins.

Nyimas. (2010). Gambaran Status Mental kognitif Pada Lansia Di Panti Sosial Tresna Werdha Margomulyo Kecamatan Puger kabupeten Jember. Diakses Januari, 11, 2011.Dari http://digilib.unej.ac.id/gdl42/gdl.p hp? $\bmod =$ browse $\&$ op=read $\& \mathrm{id}=\mathrm{gdl}$ hub-gdl-nyimasizza-2630 